\title{
Academic motivation in English online classes: A comparative study of universities in Malaysia and Indonesia
}

\author{
Suhaida Omar ${ }^{1 *}$, Wan Yusoff Wan Shaharuddin ${ }^{1}$, Nik Ahmad Farhan Azim @ Nik Azim ${ }^{1}$, \\ Noor Syamimie Mohd Nawi ${ }^{1}$, Noraini Zaini ${ }^{1}$, and Wandi Syahfutra ${ }^{2}$ \\ ${ }^{1}$ English Language Unit, Faculty of Language Studies and Human Development, \\ Universiti Malaysia Kelantan, 16300 Bachok, Kelantan, Malaysia \\ ${ }^{2}$ English Education Department, Universitas Muhammadiyah Riau, \\ Hangtuah Ujung Pekanbaru 28294, Indonesia
}

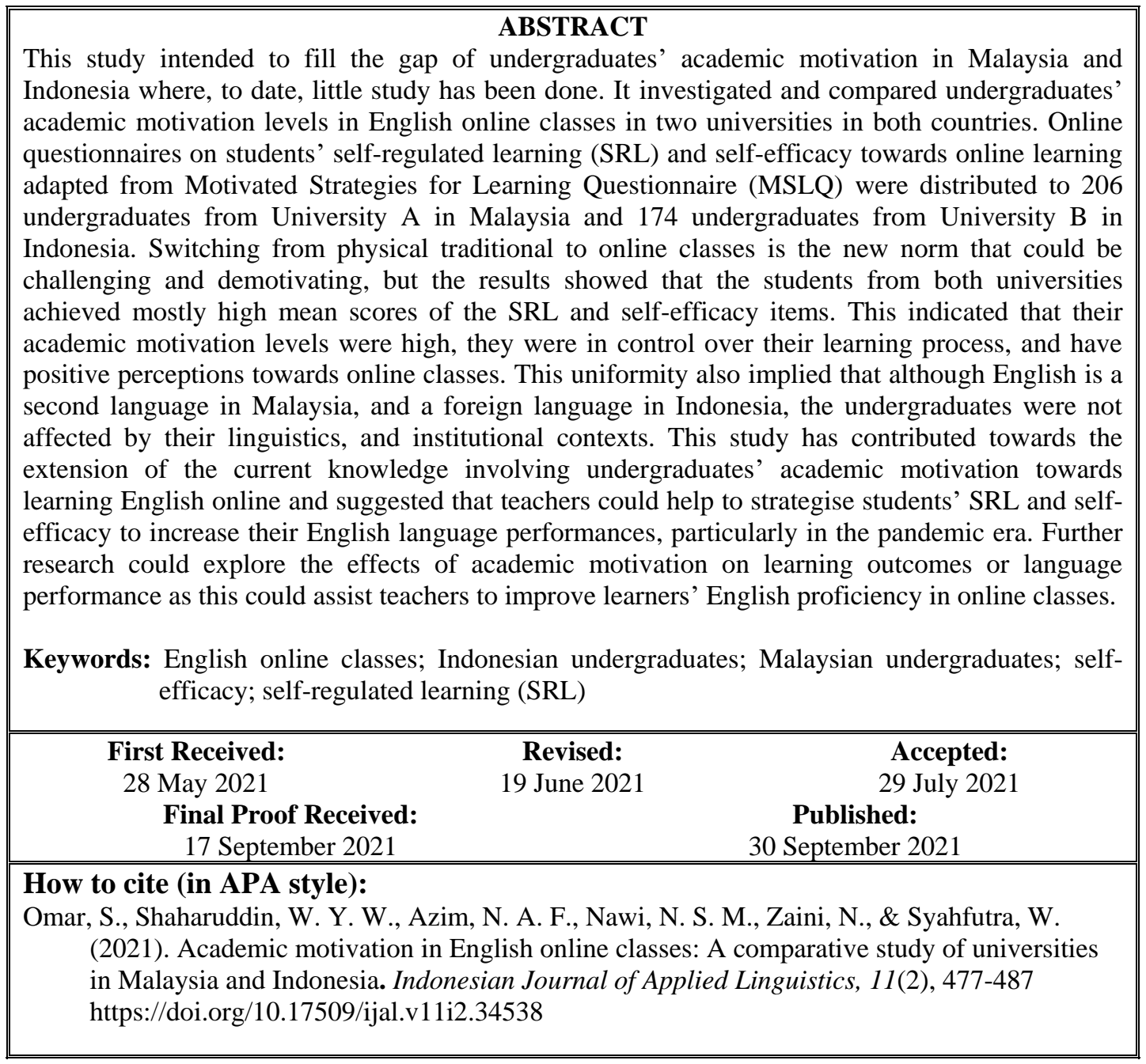

\section{INTRODUCTION}

The adoption of online learning has changed the global setting of the education system and in universities in Malaysia and Indonesia, for example, there are drastic changes such as having only a small number of students attending physical classes at the universities whilst others would study online at home, particularly due to the pandemic of
Covid-19 in December 2019 (Aliyyah et al., 2020; Al-Kumaim et al. 2021; Chung et al., 2020; Wulanjani \& Indriani, 2021). In Malaysia, the Ministry of Higher Education has directed all universities to conduct online classes since March 2020 to avoid the spread of Covid-19 among the students (Malaysian Ministry of Higher Education, 2020), and likewise, the Ministry of Education and

\footnotetext{
*Corresponding Author

Email: suhaida.o@umk.edu.my
} 
Culture in Indonesia has also instructed the change of conventional classes to online learning so that the students could continue with their studies (Wulanjani \& Indriani, 2021). Online learning is thus seen as a replacement in lieu of physical classrooms. This is the new norm but switching learning mode from traditional to online classes may not be an easy task for the students and this has raised some concerns about their readiness, motivation, performance, satisfaction, and assessment. In response to the current context of online classes, Chung et al. (2020, p.54) reported that some undergraduates were not prepared for online learning and listed various challenges such as their difficulties to focus and understand the learning content during online classes, as well as the "lack of motivation due to the absence of faceto-face contacts".

Next, a study by Wulanjani and Indriani (2021, p. 53) also stated that although the Indonesian undergraduates "generally indicated that they were ready for online learning", there were some problems such as difficulties to handle online distractions and time management which affected their learning satisfaction and quality and, subsequently their learning performance. Both studies by Chung et al. (2020) and Wulanjani and Indriani (2021) stated that the undergraduates were not confident in asking questions during the online meeting which was one of the challenges that could hinder their participation in online learning.

\section{Motivation in language teaching and learning}

Motivation in language learning is getting a lot of attention since it is considered as one of the powerful factors in assisting or hindering the students' learning performance (Lee et al., 2020; Omar et.al., 2020). In the past, students learnt English in a traditional classroom environment with the physical presence of teachers as the immediate authority in the classes who could motivate the students (Dörnyei \& Ushioda, 2011; Muslim et al., 2020; Tanaka, 2017). This referred to teachers as the decision-makers who also have the responsibility to teach and guide students throughout the learning process. Likewise, students would depend on teachers in assisting them in improving their language performances. Besides that, students were not distracted by technologies such as personal smartphones, tablets and laptops in these traditional classes which made it easier for teachers to execute their roles as the authoritative figures.

However, the disposition of students' motivation may differ from the traditional classroom environment in online classes. In the current pandemic situation whereby most education institutions in Malaysia and Indonesia have opted for online classes, students are physically separated from their teachers and peers. For instance, the ambience would not be similar to having a physical group discussion as the students could only interact on-screen with their group members, and the teacher could only monitor them from afar. Learning is a part of social activities and thus, the feeling of being isolated and having less tangible direct interactions could reduce the students' motivation since they would not get much social support from their teachers and classmates (Dörnyei \& Ushioda, 2011). Some studies cited the lack of motivation in online classes was due to the problems with the internet connection, and delayed feedback from the teachers, and these would not be likely to happen in physical classes (Allam et al., 2020; Chung et al., 2020; Wulanjani \& Indriani 2021). On the contrary, students would have to adopt the self-learning concept, need to be highly motivated, and engaged in online tasks to succeed in this situation (Hartnett, 2016; Sansone, 2011). These contexts would be related to learner readiness for online learning, but as reported by Chung et al. (2020, p. 55), "more than half of the respondents indicated that if given a choice, they did not want to continue with online learning next semester" since they were not familiar with selfdirected learning and having difficulties in engaging in online lessons.

Limited studies have been done to compare undergraduates' academic motivation in learning the English language online in the contexts of learning English as a second language (ESL) in Malaysia, and as a foreign language (EFL) in Indonesia as most were on individual context (Allam et al., 2020; Chung et al., 2020; Latip et al., 2020; Wulanjani \& Indriani 2021). Researching this topic could provide insights on the effects of the linguistics contexts such as ESL and EFL, as well as the institutional contexts such as University A in Malaysia and University B in Indonesia on their levels of academic motivation in English online classes.

The working definition of academic motivation in the context of this study constitutes self-regulated learning (SRL) and self-efficacy. Thus, this study intended to identify and compare the levels of SRL, and (2) self-efficacy of the undergraduates of University A (Malaysia) and University B (Indonesia) in English online classes.

\section{Self-regulated learning (SRL)}

Generally, self-regulated learning could be referred to as one's ability to take control and be responsible for their own learning (Schraw et al., 2006). In an online situation, the extent of SRL could affect the students' learning when they are not able to attend the classes physically. This was supported by findings from Artino Jr. and Stephens (2009) who compared two groups of students in the United States and revealed that both graduate students and undergraduates displayed SRL 
behaviours though the former reported a higher level than the latter. Next, a study by Littlejohn et al. (2016) in a university in the US reported students with low SRL were more motivated in completing the online course successfully rather than relating it to their future work (Littlejohn et al., 2016).

SRL is closely related to learner autonomy in which individual student monitors and strategies his or her own learning process. In Asian countries like Hong Kong, South Korea, and Taiwan (Cheng \& Dörnyei, 2007; Guilloteaux \& Dörnyei, 2008; Lee \& Lin, 2019), learner autonomy was rated as the least important feature and least frequently practised in the English language classes, which could be associated with the conservative Asian cultural tradition that teachers know better (Omar et al., 2020). This was reflected in an earlier study by Kaur and Sidhu (2010) in a university in Malaysia that the undergraduates lacked the confidence needed to learn autonomously, mainly because their instructors did not respond to them on time. This could be interpreted that the level of their dependency on teachers was quite high. Also, in line with the tradition that teachers are the authority figure in the classroom, Melvina and Julia (2021, p. 812) reported that some factors that inhibited the implementation of learner autonomy were "the curriculum in Indonesia, where learning objectives, plans, materials, topics were usually determined by policyholders or lecturers".

Malaysia and Indonesia are in Southeast Asia along with Brunei, Burma (Myanmar), Cambodia, Timor-Leste, Laos, Philippines, Singapore, Thailand, and Vietnam. As neighbouring countries, Malaysia and Indonesia may share some cultural traditions but English carries a different status in both countries. Comparing the linguistics and institutional contexts (ESL at University $A$ in Malaysia vs EFL at University B in Indonesia) could provide insights on respective university undergraduates' perceptions of their SRL and the practice of learner autonomy among them.

\section{Self-efficacy}

Perceptions of self-efficacy refer to a student's assessment of how well they can perform and achieve success in a learning task and situation (Zimmerman, 2000). Putra et al. (2019) reported that undergraduates in Indonesia perceived selfefficacy as a mediating variable to strengthen the influence of learning motivation in improving the quality of online learning. This finding supported the statement by Bandura (1997, p. 194) that, "The stronger the perceived self-efficacy, the more active the efforts". Next, Agustiani et al. (2016) in their study also in Indonesia revealed that selfefficacy was positively correlated with students' academic achievements which showed that when students had high self-efficacy, they performed better. Based on both studies, it could be concluded that self-efficacy has a positive impact in academic contexts, and it could, to some extent, influence students' levels of performance.

In the Malaysian context, Badiozaman et al. (2019) explained that the 838 undergraduates from four universities generally have a positive perception regarding their academic capabilities in learning ESL although they rated their English language proficiency as low. This study also reported on the strong and positive relationship between students' academic self-efficacy in ESL and their English language competence. Also, Latip et al. (2020) indicated that students with high selfefficacy would have a better understanding of the lessons, and this could contribute to learning achievement. Hence, these studies indicated that students who perceived themselves as having selfefficacy would commit to achieving their learning attainments.

Results of the cited studies suggest that there is still much to explore on the relationship between SRL and self-efficacy in online learning environments, such as differences between students from different linguistics contexts (ESL vs EFL) and different institutional contexts (University A in Indonesia vs University B in Indonesia) show similar or different responses in rating their SRL and self-efficacy. Conducting research in identifying the possibility of relationships between these variables among the undergraduates in the universities in Malaysia and Indonesia could provide more understanding and information on this matter. Therefore, the objectives of this study were,

1. identifying and comparing the levels of SRL of the undergraduates of University $A$ and University B in English online classes, and

2. identifying and comparing the levels of self-efficacy of the undergraduates of University A and University B in English online classes

\section{METHOD \\ Research design}

This study adopted the quantitative approach which was considered suitable since it could capture a broad view and collect data across groups of people in describing a specific phenomenon. Babbie (2010) also highlights that quantitative research focuses on objective measurement with the assistance of numerical and statistical analysis of data derived from distributed questionnaires. Other than that, the quantitative approach is also applicable in this study as the researcher involved were deductive testing, evading bias, aware of alternate explanations and also capable of 
generalising and replicating their findings with a different population (Creswell, 2014).

Questionnaires are generally designed to accommodate the collection of quantitative data, as the researchers would be experiencing the privilege of distributing the questionnaires electronically (Sekaran \& Bougie, 2016). Thus, the technique used involved distributing the questionnaire through an online survey posted on students' message boards of their respective courses and this was the most practical method since all the participants were at home and not around at their respective universities.

The items of Self-Efficacy and SRL were derived from the Motivated Strategies for Learning Questionnaire (MSLQ) by Pintrich and De Groot (1990). The first part of the questionnaire was on the demographic information of the participants such as their language course and location e.g., University A, Malaysia and University B,
Indonesia. The second part of the questionnaire was adapted from Pintrich and De Groot (1990) which has been used in many research studies on academic motivation beliefs for conventional physical and online classes (Artino Jr. \& Stephens, 2009; Lee et al., 2020; Littlejohn et al., 2016; Wang et al., 2013) and the subscales used in this study were Self-Efficacy with 9 items, and SRL with 9 items.

The participants responded to the 18 items of Self-efficacy and Self-regulation on a 7-point Likert scale $(1=$ not at all true of me to $7=$ very true of me). Data were later analysed using descriptive statistics to achieve the research objectives.

\section{Research sites and participants}

To provide a more comprehensive understanding of the research sites and participants, the details are portrayed in Table 1.

Table 1

The Research participants of University $A$ and University $B$

\begin{tabular}{|c|c|c|}
\hline & University A (Malaysia) & University B (Indonesia) \\
\hline Age range & \multicolumn{2}{|c|}{ Between 19-22 years old } \\
\hline Duration & \multirow{2}{*}{\multicolumn{2}{|c|}{$\begin{array}{l}\text { Semester } 1 \text { students of September 2020/2021 } \\
\text { taking first English course during the completion of the study. }\end{array}$}} \\
\hline Requirement & & \\
\hline Distributed to & 230 students & 212 students \\
\hline $\begin{array}{l}\text { Final number of } \\
\text { responses }\end{array}$ & $\begin{array}{c}206 \text { responses ( } 24 \text { responses or } 10.4 \% \text { were } \\
\text { deemed as invalid due to factors such as } \\
\text { redundant responses and incomplete } \\
\text { questionnaire forms) }\end{array}$ & $\begin{array}{l}174 \text { (38 responses or } 18 \% \text { were deemed as } \\
\text { invalid due to factors such as redundant } \\
\text { responses and incomplete questionnaire form) }\end{array}$ \\
\hline
\end{tabular}

This study took place in one public university in Malaysia and a private university in Indonesia. As neighbouring countries, Malaysia and Indonesia share a lot of similarities rather than differences at many levels. For instance, the national languages of both countries are closely related, as well as their cultures, history, and religions. In terms of the education system, in Indonesia, English is a foreign language, and it has no official status as a language of governance or usefulness in daily life. Meanwhile, in Malaysia, English is accepted as a second language, secondary importance after the Malay language in the ranking of languages of Malaysia. The use of English in various areas such as education, technology, sciences, entertainment, business, and trade has further raised its importance in the Malaysian context.

In terms of ethical consideration, the participants were notified about the objectives of this research, and they went through the questionnaire prior to answering them. They were also assured that their personal data such as name and student card or matric number will only be available to the research team.

\section{Data Analysis}

The data obtained from this study were analysed using the SPSS, or Statistical Package for Social Science (SPSS) software. Data were first filtered and three items that were considered as negative items have undergone the reverse coding procedure as recommended by Pintrich and De Groot (1990). In order to analyse the normality of data, the following numerical and visual assessments must be conducted. First and foremost, the skewness and kurtosis $\mathrm{z}$-values were analysed by dividing the skewness measure with its standard error (See Table 2). The z-values should be somewhere between -1.96 and +1.96 (Doane \& Seward, 2011).

Table 3 shows that all p-values were above 0.05 , indicating that all data were normally distributed, and the null hypothesis was supported (Razali \& Wah, 2011).

A visual inspection towards the histogram, normal Q-Q plots and box plots indicated that the mean score of Self-Efficacy and SRL for both universities were approximately normally distributed. 
Table 2

Skewness and Kurtosis z-values

\begin{tabular}{cccccc}
\hline Scale & Group & & Statistic & Std. Error & z-value \\
\hline Self-Efficacy & University A & Skewness & -.149 & .169 & -.88 \\
& & Kurtosis & -.456 & .337 & -1.35 \\
& University B & Skewness & -.102 & .184 & -.55 \\
& & Kurtosis & -.394 & .366 & -1.08 \\
\hline Self-Regulation & University A & Skewness & .149 & .169 & 0.88 \\
& & Kurtosis & -.375 & .337 & -1.11 \\
& University B & Skewness & .206 & .184 & 1.12 \\
& & Kurtosis & .067 & .366 & 0.18 \\
\hline
\end{tabular}

Table 3

Test of Normality

\begin{tabular}{|c|c|c|c|c|c|c|c|}
\hline \multicolumn{8}{|c|}{ Tests of Normality } \\
\hline & \multirow{2}{*}{ Group } & \multicolumn{3}{|c|}{ Kolmogorov-Smirnova } & \multicolumn{3}{|c|}{ Shapiro-Wilk } \\
\hline & & Statistic & df & Sig. & Statistic & df & Sig. \\
\hline \multirow{2}{*}{ Self-efficacy } & Uni A & .048 & 206 & $.200^{*}$ & .987 & 206 & .051 \\
\hline & Uni B & .069 & 174 & .042 & .986 & 174 & .072 \\
\hline \multirow{2}{*}{ Self-regulation } & Uni A & .071 & 206 & .014 & .988 & 206 & .071 \\
\hline & Uni B & .064 & 174 & .080 & .989 & 174 & .181 \\
\hline
\end{tabular}

*. This is a lower bound of the true significance.

a. Lilliefors Significance Correction

The reliability test was conducted for both scales, resulting in the Cronbach alpha value of 0.78 and 0.70 for the Self-Efficacy and SRL scale respectively.

Next, Table 4 below displays the interpretation of mean analysis for each item of SRL and self-efficacy of the questionnaire, which would be used to analyse items in Tables 6 and 7 .

\section{Table 4}

Mean range interpretation for each item of SRL and self-efficacy

\begin{tabular}{cc}
\hline Range of Mean & Interpretation \\
\hline $1.00-2.99$ & Low \\
$3.00-4.99$ & Moderate \\
$5.00-7.00$ & High \\
\hline
\end{tabular}

Finally, Table 5 shows the mean range interpretation of SRL and self-efficacy scales, which would be used to interpret the overall mean score of SRL and self-efficacy of Tables 8 and 9.

\section{Table 5}

Mean range interpretation for Self-Efficacy and Self-Regulation Scale as a whole

\begin{tabular}{cc}
\hline Range of Mean & Interpretation \\
\hline $9.00-26.99$ & Low \\
$27.00-44.99$ & Moderate \\
$45.00-63.00$ & High \\
\hline
\end{tabular}

\section{FINDINGS}

\section{Descriptive statistics}

The aim of this study was to identify how undergraduates in two universities in Malaysia and Indonesia perceived academic learning motivation in English online classes when measured through SRL and self-efficacy items.
Findings on self-regulated learning (SRL)

Table 6 shows the findings on the score of means (M) and standard deviation (SD) of the SRL items based on the participants' answers from both universities.

Based on Table 6, a total of 6 items in SRL scale for University A which were Item 1, Item 3, Item 4, Item 5, Item 8 and Item 9 were categorised as the items with high mean score (refer to Table $4)$. The mean analysis indicated that Item $4(M=$ 5.92, $S D=1.030$ ) had the highest mean score among the six high scoring items followed by Item $1(M=5.91, S D=0.969)$, Item $5(M=5.85, S D=$ $0.953)$, Item $8(M=5.70, S D=1.102)$, Item $9(M=$ $5.92, S D=1.449)$ and Item $3(M=5.47, S D=$ 1.167). On the other hand, three items were categorised as having moderate mean score which were Item $7(M=4.46, S D=1.619)$, Item $2(M=$ $4.43, S D=1.668)$ and Item $6(M=4.10, S D=$ $1.508)$, in which the lowest mean score was recorded.

Next, Table 6 also shows the mean analysis of each item in SRL scale for University B. A total of five items which were Item 1 , Item 4, Item 5, Item 8 , and Item 9 were categorised as the items with high mean score (refer to Table 4). The mean analysis indicated that Item $4(M=5.78, S D=$ 1.26) had the highest mean score among the five high scoring items followed by Item $5(M=5.41$, $S D=1.20)$, Item $9(M=5.39, S D=1.52)$, Item 8 $(M=5.37, S D=1.27)$, and Item $1(M=5.18, S D=$ 1.23). On the other hand, four items were categorised as having moderate mean score which were Item $3(M=4.64, S D=1.51)$, Item $7(M=$ $4.00, S D=1.75)$, Item $6(M=3.72, S D=1.62)$, and 
item $2(M=3.25, S D=1.39)$ in which the lowest mean score was recorded.

There are some interesting matters based on Table 6. Firstly, undergraduates from both universities scored high means across five SRL items which were Item 1, Item 4, Item 5, Item 8, and Item 9. Next, they also scored moderate means in three items which were Item 2 , Item 6 , and Item
7. Finally, Item 3 was the only item that they scored differently in which undergraduates from University A scored high, and their counterparts in University B scored moderate.

Table 7 shows the findings on the score of means (M) and standard deviation (SD) of the selfefficacy items based on the participants' answers from both universities.

Table 6

The mean analysis of each item of SRL of University A and University B

\begin{tabular}{|c|c|c|c|c|c|c|}
\hline \multirow[t]{2}{*}{ Items } & \multicolumn{3}{|c|}{ University A } & \multicolumn{3}{|c|}{ University B } \\
\hline & $\mathbf{M}$ & SD & Interpretation & $\mathbf{M}$ & SD & Interpretation \\
\hline $\begin{array}{l}\text { 1. I ask myself questions to make sure } \\
\text { I know the material I have been } \\
\text { studying. }\end{array}$ & 5.91 & 0.969 & High & 5.18 & 1.23 & High \\
\hline $\begin{array}{l}\text { 2. When work is hard I either give up } \\
\text { or study only the easy parts. }(* \mathrm{R})\end{array}$ & 4.43 & 1.668 & Moderate & 3.25 & 1.39 & Moderate \\
\hline $\begin{array}{l}\text { 3. I work on practice exercises and } \\
\text { answer questions even when I don't } \\
\text { have to. }\end{array}$ & 5.47 & 1.167 & High & 4.64 & 1.51 & Moderate \\
\hline $\begin{array}{l}\text { 4. Even when study materials are dull } \\
\text { and uninteresting, I keep working } \\
\text { until I finish. }\end{array}$ & 5.92 & 1.030 & High & 5.78 & 1.26 & High \\
\hline $\begin{array}{l}\text { 5. Before I begin studying, I think } \\
\text { about the things I will need to do to } \\
\text { learn. }\end{array}$ & 5.85 & 0.953 & High & 5.41 & 1.20 & High \\
\hline $\begin{array}{l}\text { 6. I often find that I have been reading } \\
\text { for class but don't know what it is all } \\
\text { about. }(* \mathrm{R})\end{array}$ & 4.10 & 1.508 & Moderate & 3.72 & 1.62 & Moderate \\
\hline $\begin{array}{l}\text { 7. I find that when the teacher is } \\
\text { talking I think of other things and } \\
\text { don't really listen to what is being } \\
\text { said. }(* \mathrm{R})\end{array}$ & 4.46 & 1.619 & Moderate & 4.00 & 1.75 & Moderate \\
\hline $\begin{array}{l}\text { 8. When I'm reading, I stop once in a } \\
\text { while and go over what I have read. }\end{array}$ & 5.70 & 1.102 & High & 5.37 & 1.27 & High \\
\hline $\begin{array}{l}\text { 9. I work hard to get a good grade even } \\
\text { when I don't like a class. }\end{array}$ & 5.62 & 1.449 & High & 5.39 & 1.52 & High \\
\hline
\end{tabular}

$* \mathrm{R}=$ Negative item which requires reverse coding during data analysis.

Table 7

The Mean Analysis of Each Item of Self-Efficacy of University A and University B

\begin{tabular}{|c|c|c|c|c|c|c|}
\hline \multirow[b]{2}{*}{ Items } & \multicolumn{3}{|c|}{ University A } & \multicolumn{3}{|c|}{ University B } \\
\hline & M & SD & Interpretation & M & SD & Interpretation \\
\hline $\begin{array}{l}\text { 1. Compared with other students in } \\
\text { this class I expect to do well. }\end{array}$ & 5.84 & 1.023 & High & 5.94 & 1.27 & High \\
\hline $\begin{array}{l}\text { 2. I'm certain I can understand the } \\
\text { lessons taught in this class. }\end{array}$ & 6.01 & 0.905 & High & 5.60 & 0.18 & High \\
\hline $\begin{array}{l}\text { 3. I expect to do very well in this } \\
\text { class. }\end{array}$ & 6.45 & 0.781 & High & 6.13 & 1.07 & High \\
\hline $\begin{array}{l}\text { 4. Compared with others in this class, } \\
\text { I think I'm a good student. }\end{array}$ & 4.57 & 1.473 & Moderate & 4.66 & 1.44 & Moderate \\
\hline $\begin{array}{l}\text { 5. I am sure I can do an excellent job } \\
\text { on the activities and tasks assigned } \\
\text { for this class. }\end{array}$ & 5.86 & 0.970 & High & 5.41 & 1.16 & High \\
\hline $\begin{array}{l}\text { 6. } 1 \text { think I will receive a good grade } \\
\text { in this class. }\end{array}$ & 5.48 & 1.081 & High & 5.20 & 1.22 & High \\
\hline $\begin{array}{l}\text { 7. My study skills are excellent } \\
\text { compared with others in this class. }\end{array}$ & 4.27 & 1.404 & Moderate & 4.28 & 1.52 & Moderate \\
\hline $\begin{array}{l}\text { 8. Compared with other students in } \\
\text { this class I think I know a great } \\
\text { deal about the subject (English } \\
\text { language). }\end{array}$ & 4.13 & 1.429 & Moderate & 4.26 & 1.61 & Moderate \\
\hline $\begin{array}{l}\text { 9. I know that I will be able to learn } \\
\text { the material for this class. }\end{array}$ & 5.98 & 0.950 & High & 5.52 & 1.09 & High \\
\hline
\end{tabular}


Based on Table 7, a total of 6 items in SelfEfficacy scale for University A which were Item 1, Item 2, Item 3, Item 5, Item 6 and Item 9 were categorised as the items with high mean score (refer to Table 4). The mean analysis indicated that Item $3(M=6.45, S D=0.781)$ had the highest mean score among the six high scoring items followed by Item $2(M=0.601, S D=0.905)$, Item $9(M=5.98, S D=0.950)$, Item $5(M=5.86, S D=$ $0.970)$, Item $1(M=5.84, S D=1.023)$ and Item 6 $(M=5.48, S D=1.081)$. On the other hand, three items were categorised as having moderate mean score which were Item $4(M=4.57, S D=1.473)$, Item $7(M=4.27, S D=1.404)$ and Item $8(M=$ $4.13, S D=1.429)$, in which the lowest mean score was recorded.

Next, Table 7 also shows the mean analysis of each item in Self-Efficacy scale for University B. A total of six items which were Item 1, Item 2, Item 3 , Item 5, Item 6 and Item 9 were categorised as the items with high mean score (refer to Table 4). The mean analysis indicated that Item $3(M=6.13, S D$
$=1.07)$ had the highest mean score among the six high scoring items followed by Item $1(M=5.94$, $S D=1.27)$, Item $2(M=5.60, S D=0.18)$, Item 9 $(M=5.52, S D=1.09)$, Item $5(M=5.41, S D=$ 1.16) and Item $6(M=5.20, S D=1.22)$. On the other hand, three items were categorised as having moderate mean score which were Item $4(M=4.66$, $S D=1.44)$, Item $7(M=4.28, S D=1.52)$ and Item $8(M=4.26, S D=1.61)$, in which the lowest mean score was recorded.

Table 7 presented more interesting findings in which the undergraduates from both universities scored high means across six self-efficacy items which were Item 1 , Item 2 , Item 3 , Item 5, Item 6, and Item 9. Then, they also scored moderately for the other three items which were Item 4, Item 7 , and Item 8 .

Table 8 below presents the summary of mean analysis (M) and standard deviation (SD) of the undergraduates' SRL scale between University A and University B.

Table 8

Summary of mean analysis of SRL between University A and University B

\begin{tabular}{lcccc}
\hline Self-Regulation & Mean $(\boldsymbol{M})$ & Std. Deviation $(\boldsymbol{S D})$ & Interpretation & $\boldsymbol{n}$ \\
\hline University A & 47.45 & 6.33 & High & 206 \\
University B & 42.75 & 5.44 & Moderate & 174 \\
\hline
\end{tabular}

Based on Table 8 , the mean score for the SRL scale was $M=47.45, S D=6.33$ for undergraduates of University A, and for the University B undergraduates, the mean score for SRL was $M=$ $42.75, S D=5.44$. Thus, the result showed that University A's undergraduates displayed higher mean scores than their peers at University B who showed a moderate mean score (refer to Table 5).

Meanwhile, Table 9 below presents the summary of mean analysis (M) and standard deviation (SD) of the undergraduates' self-efficacy scale between University A and University B.

Table 9

Summary of mean analysis of Self-Efficacy between University A and University B

\begin{tabular}{lcccc}
\hline Self-Efficacy & Mean $(\boldsymbol{M})$ & Std. Deviation $(\boldsymbol{S D})$ & Interpretation & $\boldsymbol{n}$ \\
\hline University A & 48.57 & 6.16 & High & 206 \\
University B & 47.00 & 7.95 & High & 174 \\
\hline
\end{tabular}

Table 9 shows the mean score for the SelfEfficacy scale was $M=48.57, S D=6.16$ for University A's undergraduates, and it was $M=$ 47.00, $S D=7.95$ for undergraduates of University B. In contrast to their overall mean scores of SRL, they showed a similar overall high mean score for their self-efficacy.

\section{DISCUSSION}

Identification and comparison of the levels of SRL of the University $A$ and University $B$ undergraduates in English online classes

Table 6 has shown that undergraduates from University A and University B achieved high mean scores of five SRL items such as their perseverance in completing tasks that were considered as boring and monotonous, as well as being mentally prepared prior to study. They also agreed that they would work hard for good grades even if they were not interested in the lessons, pay attention in classes and they would continue studying even if the tasks were difficult. Next, there were three negatively worded items such as not paying attention to teacher talk, giving up when the tasks were difficult and being clueless about the lessons. They were analysed through reversed coding, and since the undergraduates displayed moderate mean scores for these items, it indicated that they were positive and persistent towards their SRL. These data were in line with the findings by Littlejohn et al. (2016) that they considered online learning as a formal learning task that should be taken seriously, and undergraduates have high self-regulation in 
online learning (Artino Jr. \& Stephens, 2009). In general, these undergraduates of University A and University B shared similar perceptions on their SRL, and the only difference between them was only about Item 3 which was revising lessons on their own in which the former group rated the item highly and the latter rated it moderately.

Next, Table 8 portrayed the overall mean scores of SRL of the undergraduates which implied that they have a range of moderate to high levels of SRL (University A; 47.45 and University B; 42.75). As mentioned earlier, the only difference between these groups was only Item 3, whereby University A's students scored $M=5.47, S D=$ 1.167 , and $M=4.64, S D=1.51$ by University B's students, which could be considered as a slight difference. It could also be implied that University A's students perceived self-revision as slightly more important than University B's students. Pintrich and De Groot (1990) stated that SRL items were based on metacognitive and management strategies. In relation to this, since both groups showed high and moderate responses to these eight SRL items, it could be concluded that they have good mental and management strategies for language learning during their English online classes.

Besides that, it could be concluded these students were aware that they were responsible for their own learning and such attitudes would be beneficial during online classes since the teachers would not be there to monitor them like in a traditional classroom. Online environment could also provide the platform for individual students "to actively engage in and regulate learning activities" (Sansone et al., 2011, p. 200), and since the undergraduates in this study displayed more high levels of SRL, it indicated they were able to participate and perhaps support each other during online classes.

In addition, this finding also showed that the students were moving towards learner autonomy which was similar to the results in the studies by studies by Kaur and Sidhu (2010) and Melvina and Julia

(2021) as they stated that there was a positive correlation between learner autonomy and language proficiency, the students were aware of the importance of learner autonomy and there were opportunities for it to be implemented. However, the teachers would have to play an important role in scaffolding the students towards learner autonomy since it is not a common practice among Asian students. This would be a challenge, but it is worth trying it out.

Finally, Lee et al. (2020) suggested that learning contexts could influence the levels of students' SRL but the undergraduates in this study who came from two different settings (University $A$ and University B) did not show any discrepancies in relation to their mean scores in SRL. This could be associated with the context of Malaysia and Indonesia in the Asian region and as neighbouring countries, they share some similar cultural, religious and national linguistics values.

\section{Identification and comparison of the levels of self-efficacy of University $A$ and University $B$ undergraduates in English online classes}

As stated much earlier, students with high selfefficacy have more determination and are more likely to accomplish their tasks. Table 7 has presented that the undergraduates from University A and University B showed a consistent high mean score of six self-efficacy items and moderate mean score of the other three. In addition, Table 9 depicted the overall mean scores of the undergraduates' self-efficacy (University A; 48.57 and University B; 47.00). These findings implied that the undergraduates were adaptive to the online classes and although the teachers and classmates were not physically around, this did not deprive them of participating actively in their online classes. This is consistent with previous results on self-efficacy as one of the motivational factors during online classes by Agustiani et al. (2016), and Littlejohn et al. (2016), and Putra et al. (2019), that self-efficacy had a positive and significant effect on the quality of E-Learning.

Self-efficacy is related to how one views himself or herself while performing a task including their capabilities of organising and completing the task (Bandura, 1997). In other words, it would be individuals competing against themselves and not against each other. Online classes signify the physical absence of teachers and classmates and therefore, the students would have to depend more on themselves during the lessons and challenge themselves to improve their learning performances. Since the findings of this study showed that the undergraduates rated themselves high in the self-efficacy scale, this indicated that their academic motivation levels were high, they were in control over their learning process and have positive perceptions towards online classes despite learning English online at home without physical appearance of teachers and peers.

Finally, in response to the earlier enquiry of whether linguistics and institutional contexts (ESL at University A in Malaysia vs EFL at University B in Indonesia), since the overall mean scores of the undergraduates from both universities are quite close, it indicated there was no linguistics and institutional influences on their levels of selfefficacy as they remained high despite the shift from physical traditional to online classes. It could also be interpreted that the undergraduates of both universities were aware that online classes would be continued even after the decrease of the Covid- 
19 pandemic, and thus, self-learning would be one of the ways forward in learning English online.

\section{CONCLUSION}

This study has sought to investigate the differences in academic motivation levels in online classes between undergraduates in higher education institutions in Malaysia and Indonesia.

The major finding from this study was that undergraduates from both universities showed high self-regulation learning and self-efficacy mean scores. Next, it is interesting to note that although English is regarded as the second language in Malaysia and a foreign language in Indonesia, the undergraduates were not linguistically and institutionally attached, as they showed interest in their English online classes. Perhaps the status of English as an international language has increased its importance to these undergraduates particularly in relation to future careers.

There are some limitations to these findings, however. First only the questionnaire was used in this study for data collection. Although it was a good instrument to collect data from a large number of respondents, it did not capture enough of the insights of undergraduates' views on their SRL and self-efficacy. Next, the undergraduates' language performance in relation to their SRL and self-efficacy was not researched in this study, mainly because the aim was to compare their SRL and self-efficacy between two learning contexts.

This study has contributed towards the extension of the current knowledge involving undergraduates' academic motivation towards learning English online. With the utilisation of SRL and Self-Efficacy scales, the study can help current and prospective researchers or teachers to understand the levels of academic motivation among undergraduates, particularly in the era of the Covid-19 pandemic. Such findings would be essential for the education authority to understand the challenges faced by students in the current learning environment by strategizing students' SRL and self-efficacy to increase their English language performances. Therefore, the findings of this study would also help to get the attention of education authorities in both Malaysia and Indonesia in upgrading and providing the up-to-date facilities which are essential in facilitating English online classes, and subsequently promote learner autonomy.

For further research, it would be helpful to identify the effects of academic motivation on learning outcomes or language performance as this could assist the teachers to improve learner's English proficiency in online classes. Conducting a collaborative study in different institutions in Malaysia and Indonesia could provide the teachers and students to learn about academic motivation from each other. Another consideration is to research online learner autonomy since the finding could be beneficial for learners who are having difficulties with the current trend of online classes. As the pandemic is still on the loose, the policymakers and education authorities must come out with other alternatives of English online classes to ensure that students have better English language learning experiences, regardless of their geographical background.

\section{ACKNOWLEDGEMENTS}

This study was conducted under the following research grant; R/SGJP/A04.00/01380A/001/2018/000511

(Universiti Malaysia Kelantan) The researchers would like the express our appreciation to the university for the financial support provided. Authors' Contribution: All the authors made substantial contributions to the design and initial drafting of this study, to data analysis and interpretation, and to the manuscript review and writing of the final version. All the authors assume public responsibility for the content of the manuscript.

\section{REFERENCES}

Agustiani, H., Cahyad, S., \& Musa, M. (2016). Self-efficacy and self-regulated learning as predictors of students' academic performance. The Open Psychology Journal, 9(1), 1-6. http://doi.org/10.2174/1874350101609010001

Aliyyah, R. R., Rachmadtullah, R., Samsudin, A., Syaodih, E., Nurtanto, M., \& Tambunan, A. R. S. (2020). The perceptions of primary school teachers of online learning during the COVID-19 pandemic period: A case study in Indonesia. Journal of Ethnic and Cultural Studies, 7(2), 90-109. http://dx.doi.org/10.29333/ejecs/388

Al-Kumaim, N. H., Mohammed, F., Gazem, N. A., Fazea, Y., Alhazmi, A. K., \& Dakkak, O. (2021). Exploring the impact of transformation to fully online learning during Covid-19 on Malaysian university students' academic life and performance. International Journal of Interactive Mobile Technologies, 15(5), 140-158. https://doi.org/10.3991/ijim.v15i05.20203

Allam, S. N. S., Hassan, M. S., Mohideen, R. S., Ramlan, A. F., \& Kamal, R. M. (2020). Online distance learning readiness during Covid-19 outbreak among undergraduate students. International Journal of Academic Research in Business and Social Sciences, 10(5), 642-657. http://doi.org/10.6007/IJARBSS/v10-i5/7236 
Artino Jr, A. R., \& Stephens, J. M. (2009). Academic motivation and self-regulation: A comparative analysis of undergraduate and graduate students learning online. The Internet and Higher Education, 12(3-4), 146151. https://doi.org/10.1016/j.iheduc.2009.02.001

Babbie, E. (2010). The practice of social research (13th ed.). Wadsworth Cengage Learning.

Bandura, A. (1997). Self-efficacy the exercise of control. W. H. Freeman and Company.

Badiozaman, I. F. A., Leong, H. J., \& Jikus, O. (2019). Students' perception and use of English in higher education institutions: Links with academic self-efficacy. Journal of Applied Research in Higher Education, 11(1), 36-49. https://doi.org/10.1108/JARHE-072018-0113

Cheng, H. F., \& Dörnyei, Z. (2007). The use of motivational strategies in language instruction: The case of EFL teaching in Taiwan. International Journal of Innovation in Language Learning and Teaching, 1(1), 153-174. https://doi.org/10.2167/illt048.0

Chung, E., Subramaniam, G., \& Dass, L. C. (2020). Online learning readiness among university students in Malaysia amidst COVID-19. Asian Journal of University Education, 16(2), 46-58. https://doi.org/10.24191/ajue.v16i2.10294

Creswell, J. W. (2014). Research design: Qualitative, quantitative, and mixed methods approaches (4th ed.). Sage Publication.

Doane, D.P., \& Seward, L.E. (2011). Measuring Skewness: A forgotten statistic? Journal of Statistic Education, 19(2), 1-18. https://doi.org/10.1080/10691898.2011.11889 611

Dörnyei, Z., \& Ushioda, E. (2011). Teaching and researching motivation ( $2 \mathrm{nd}$ ed.). Pearson Education Limited.

Guilloteaux, M. J., \& Dörnyei, Z. (2008). Motivating language learners: A classroomoriented investigation of the effects of motivational strategies on student motivation. TESOL Quarterly 42 (1), 55-77. https://doi.org/10.2307/40264425

Hartnett, M. (2016). The importance of motivation in online learning. In M. Hartnett (Ed.), Motivation in online education (pp. 5-32). Springer.

Kaur, R., \& Sidhu, G. (2010). Learner autonomy via asynchronous online interactions: A Malaysian perspective. International Journal of Education and Development Using ICT, 6(3), 88-100. https://www.learntechlib.org/p/42386/

Latip, M. S. A., Noh, I., Tamrin, M., \& Latip, S. N. N. A. (2020). Students' acceptance for e- learning and the effects of self-efficacy in Malaysia. International Journal of Academic Research in Business and Social Sciences, 10(5), 658-674. http://doi.org/10.6007/IJARBSS/v10-i5/7239

Lee, D., Watson, S., \& Watson, W. (2020). The relationships between self-efficacy, task value, and self-regulated learning strategies in massive open online courses. International Review of Research in Open and Distributed Learning, 21(1), 23-39. https://doi.org/10.19173/irrodl.v20i5.4389

Lee, T. S., \& Lin, S. Y. (2019). English teachers' uses of motivational strategies beyond an established framework. Educational Research, 61(4), 451-468. https://doi.org/10.1080/00131881.2019.16771 70

Littlejohn, A., Hood, N., Milligan, C., \& Mustain, P. (2016). Learning in MOOCs: Motivations and self-regulated learning in MOOCs. The Internet and Higher Education, 29, 40-48. https://doi.org/10.1016/j.iheduc.2015.12.003

Malaysian Ministry of Higher Education (2020). Press Release by the Malaysian Ministry of Higher Education, retrieved from https://www.nst.com.my/news/nation/2020/05 /595758/university-lectures-go-online-untildec-31-except-5-groups

Melvina, M., \& Julia, J. (2021). Learner autonomy and English proficiency of Indonesian undergraduate students. Cypriot Journal of Educational Sciences, 16(2), 803-818. https://www.ceeol.com/search/articledetail $? \mathrm{id}=950622$

Muslim, A. B., Hamied, F. A., \& Sukyadi, D. (2020). Integrative and instrumental but low investment: The English learning motivation of Indonesian senior high school students. Indonesian Journal of Applied Linguistics, 9(3), 493-507. https://doi.org/10.17509/ijal.v9i3.23199

Omar, S., Farhan Azim, N., Mohd Nawi, N. S., \& Zaini, N. (2020). Motivational strategies among English language teachers: An examination in higher education institutions in the Malaysian context. Arab World English Journal (AWEJ), 11(3), 170-183. https://doi.org/10.24093/awej/vol11no3.10

Pintrich, P. R., \& De Groot, E. V. (1990). Motivational and self-regulated learning components of classroom academic performance. Journal of Educational Psychology, 82(1), 33-40. https://doi.org/10.1037/0022-0663.82.1.33

Putra, R. B., Ridwan, M., Mulyani, S. R., Ekajaya, D. S., \& Putra, R. A. (2019). Impact of learning motivation, cognitive and selfefficacy in improving learning quality elearning in Industrial Era 4.0. Journal of 
Physics: Conference Series, 1339(1), 012081. https://doi.org/10.1088/17426596/1339/1/012081

Razali, N. M., \& Wah, Y.B. (2011). Power comparisons of Shapiro-Wilk, KolmogorovSmirnov, Lillliefors and Anderson-Darling tests. Journal of Statistical Modelling and Analytics, 2(1), 21-33.

https://scholar.google.co.id/citations?view_op =view_citation \&hl=id\&user=KnvT0OwAAA AJ\&citation_for_view=KnvT0OwAAAAJ:d1 gkVwhDpl0C

Sansone, C., Fraughton, T., Zachary, J. L., Butner, J., \& Heiner, C. (2011). Self-regulation of motivation when learning online: The importance of who, why and how. Educational technology research and development, 59(2), 199212.https://www.jstor.org/stable/41414934

Schraw, G., Kauffman, D. F., \& Lehman, S. (2006). Self-Regulated Learning. In L. Nadel (Ed.), The encyclopedia of cognitive science (pp. 1063-1073). Macmillan.

Sekaran, U., \& Bougie, R. (2016). Research methods for busniness: A skill-building approach (7th ed.). John Wiley \& Sons.
Tanaka, M. (2017). Factors affecting motivation for short in-class extensive reading. Journal of Asia TEFL, 14(1), 98-113. https://doi.org/10.18823/asiatefl.2017.14.1.7.9 8

Wang, C., Schwab, G., Fenn, P., \& Chang, M. (2013). Self-efficacy and self-regulated learning strategies for English language learners: Comparison between Chinese and German college students. Journal of Educational and Developmental Psychology, 3(1), 173-191. https://doi.org/10.5539/jedp.v3n1p173

Wulanjani, A. N., \& Indriani, L. (2021). Revealing higher education students' readiness for abrupt online learning in Indonesia amidst Covid-19. NOBEL: Journal of Literature and Language Teaching, 12(1), 43-60. https://doi.org/10.15642/NOBEL.2021.12.1.4 3-59

Zimmerman, B. J. (2000). Self-efficacy: An essential motive to learn. Contemporary Educational Psychology, 25(1), 82-91. https://doi.org/10.1006/ceps.1999.1016 